\title{
Lung function in workers using cadmium containing solders
}

\author{
C EDLING, ${ }^{1}$ C G ELINDER,${ }^{2}$ ESTER RANDMA ${ }^{2}$
}

\begin{abstract}
From the Department of Occupational Medicine, University Hospital, S-581 85 Linköping, Department of Occupational Medicine, ${ }^{1}$ University Hospital, S-75185 Uppsala, and Department of Occupational Medicine, ${ }^{2}$ National Board of Occupational Safety and Health, S-171 84 Solna, Sweden
\end{abstract}

ABSTRACT The lung function of 57 male workers previously exposed to cadmium in connection with the use of cadmium containing solders was examined by spirometry (FVC, FEV, FEV\%, and MMF) and single breath nitrogen washout (CV, CV\%, and phase III). A reference group $(n=31)$ from a nearby industry was examined at the same time. Despite the fact that the exposure in previous years had been relatively high, in the order of $0.05-0.5 \mathrm{mg} \mathrm{Cd} / \mathrm{m}^{3}$, and that $24(42 \%)$ of the workers had cadmium induced renal damage in the form of $\beta_{2}$-microglobulinuria there was no evidence of pulmonary damage. There were no significant differences in lung function data from the exposed and reference group and there was no dose-response relation within the exposed group. It thus appears that signs of kidney toxicity in the form of low molecular weight proteinuria precede those that may be identified in the lung with commonly used lung function tests.

In 1950 Friberg reported that long term occupational exposure to cadmium could induce renal damage and obstructive lung changes. ${ }^{1}$ During the 1950 s and 1960 s additional reports of cadmium induced respiratory effects were published by investigators in the United Kingdom ${ }^{2-5}$ and West Germany. ${ }^{6}$ In the 1970s Lauwerys and coworkers in a study of 25 cadmium fume and dust exposed workers and 25 matched controls found significantly reduced forced vital capacity (FVC), forced expired volume in one second $\left(\mathrm{FEV}_{1}\right)$, and peak expiratory flow rate (PEFR). ${ }^{78}$ The exposed group had been exposed to cadmium for more than 20 years. In a later and more thorough examination of 18 of the workers the pulmonary effects from exposure to cadmium previously seen were not confirmed ${ }^{9}$ and the very existence of chronic respiratory effects from exposure to cadmium has been questioned. ${ }^{910}$ Furthermore, it has been discussed whether renal effects precede the pulmonary effects or not. ${ }^{811}$

We have examined the lung function of 57 workers exposed to cadmium in connection with the use of cadmium containing solders and 31 non-cadmium exposed referents. The objective of the-work was to examine dose response relations with regard to exposure to cadmium and early signs of obstructive lung changes and to determine whether or not renal

Accepted 3 February 1986 effects in the form of low molecular weight proteinuria precede the respiratory effects.

\section{Material and methods}

FACTORY, PRODUCTION, AND EXPOSURE LEVELS The company started to use cadmium containing solders in 1955 but no air measurements were carried out until 1976. ${ }^{12}$ Stationary measurements showed high cadmium exposure, from $0.060-0.497 \mathrm{mg}$ $\mathrm{Cd} / \mathrm{m}^{3}$, average $0.20 \mathrm{mgCd} / \mathrm{m}^{3}$. Personal samplers carried by 11 workers using cadmium containing solders showed even higher values; 0.095-1.958 mg $\mathrm{Cd} / \mathrm{m}^{3}$. Measurements one year later showed $0.091-0.191 \mathrm{mg} \mathrm{Cd} / \mathrm{m}^{3}$. In July 1978 the production hall was renovated and painted and since that date no cadmium containing solders or other materials containing significant amounts of cadmium have been used. More details about exposure are given in another report based on the same group of workers. ${ }^{13}$

EXAMINED GROUPS AND INDIVIDUAL EXPOSURE Rather more than 500 blue collar workers had been employed by the company since 1954. Sixty eight had been employed for at least five years before 1978 and it was considered likely that this subgroup would include most of the workers who might possibly show chronic effects. All, including those who were retired or working elsewhere, were invited to take part in a health examination. Two had died and 57 of the 
Table 1 Number of subjects, smoking habits, age, height, and exposure time for exposed and reference groups

\begin{tabular}{|c|c|c|c|c|c|c|c|c|c|}
\hline & \multirow[b]{2}{*}{ No } & \multirow[b]{2}{*}{ Smokers } & \multirow{2}{*}{$\begin{array}{l}\text { Non- } \\
\text { smokers }\end{array}$} & \multicolumn{2}{|c|}{ Age (years) } & \multicolumn{2}{|l|}{ Height } & \multicolumn{2}{|c|}{ Exposure time } \\
\hline & & & & Mean & $S D$ & Mean & $S D$ & Mean & $S D$ \\
\hline $\begin{array}{l}\text { Exposed } \\
\text { Referents }\end{array}$ & $\begin{array}{l}57 \\
31\end{array}$ & $\begin{array}{l}24 \\
16\end{array}$ & $\begin{array}{l}33 \\
15\end{array}$ & $\begin{array}{l}48 \\
45\end{array}$ & $\begin{array}{l}13 \\
14\end{array}$ & $\begin{array}{l}176 \\
176\end{array}$ & $\begin{array}{l}6 \\
7\end{array}$ & 14 & 7 \\
\hline
\end{tabular}

remaining 64 men (89\%) took part in this study. All four retired men took part and 31 of the 32 who were working elsewhere. Consequently most of the drop outs (6 men) were among people still employed in the company and for various reasons not taking part in the examination.

The exposed group comprised 57 men whose mean age at the time of examination was 48; the period of exposure ranged from five to 24 years with a mean of 14 years (table 1). Each individual's exposure was classified into four categories; high, medium, low, and no cadmium exposure. Welding or soldering using cadmium containing solders was classified as a high exposure. Activities carried out in the production hall, when cadmium was in use, were classified as given rise to a medium exposure. Tasks that were only partly carried out in the production hall were considered to result in a low exposure. Before 1955 and after 1978 there was no exposure at all to cadmium.

The number of years that each worker had been occupied in activities that gave rise to high, medium, low, and no exposure were recorded. Based on the measurements carried out in $1976^{12}$ it was estimated that high, medium, and low exposure was about 0.5 , $0 \cdot 15$, and $0.05 \mathrm{mg} \mathrm{Cd} / \mathrm{m}^{3}$, respectively. A cumulative dose estimate was calculated for each workers as $\mathrm{mg} \mathrm{Cd} / \mathrm{m}^{3}$ times year $\left(\mathrm{mg} \mathrm{Cd} / \mathrm{m}^{3} \cdot \mathrm{y}\right) .^{13}$

From a nearby company a reference group of 31 men was selected. They had similar work tasks (soldering, welding) but no known exposure to cadmium and were matched with regard to age and height (table 1).

QUESTIONNAIRE AND RENAL FUNCTION

Each person was asked to answer a self administered questionnaire including questions about previous and present diseases, upper airways and lung symptoms, history of renal stones, use of drugs, and smoking habits.

The renal function of each cadmium exposed worker was examined by measuring urine and serum protein concentrations; the glomerular filtration rate (GFR) using CrEDTA clearance was carried out in 17 of the workers. Further details, and the results of the study of renal function, are given elsewhere. ${ }^{13} 14$

\section{LUNG FUNCTION TESTS}

Respiratory effects were studied by spirometry and single breath nitrogen washout. Everyone, exposed and unexposed, was studied by the same nurse during a regular working day. A forced expired vital capacite manoeuvre was recorded with a low resistance bet lows spirometer (OHIO). The subject was seated an was carefully instructed before the test was performed. Each individual performed three tests. The best result for each variable was chosen, even if this $\triangle$ meant that results were selected from different record- $\overline{\bar{B}}$ ings. $^{15}$ The following variables were studied: forced expired vital capacity (FVC), forced expired volume in one second $\left(\mathrm{FEV}_{1}\right), \mathrm{FEV}_{1}$ divided by FVC times

Table 2 Frequency of symptoms and earlier diseases in upper and lower airways among the exposed and referents

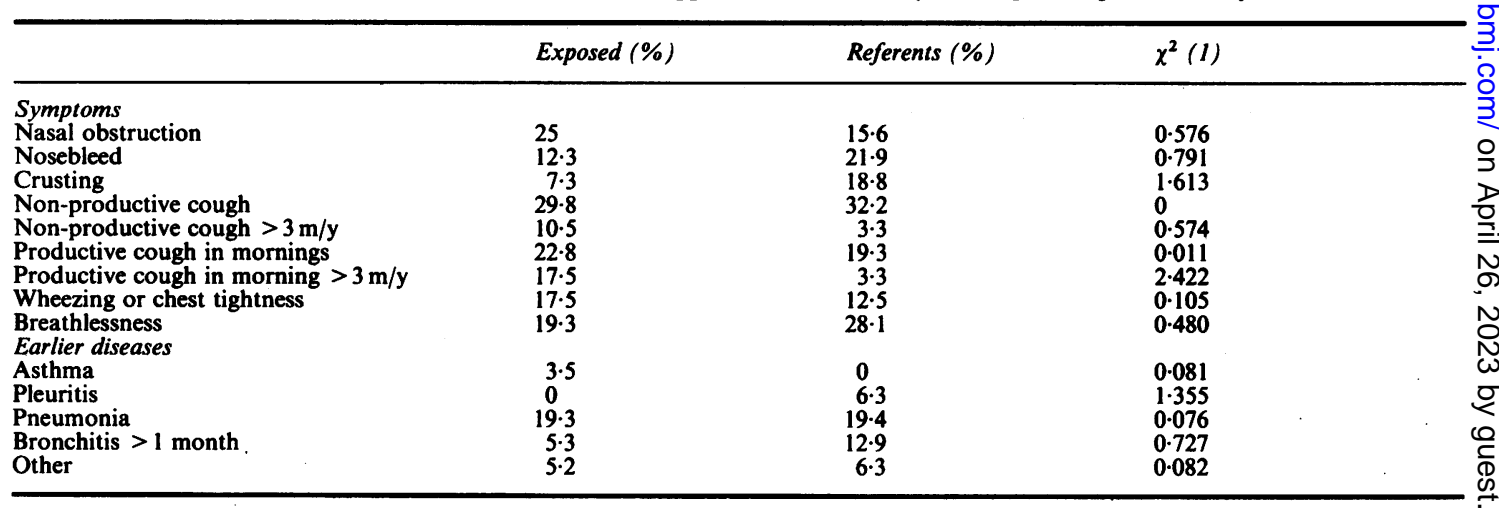


Table 3 Spirometric and nitrogen washout data from the exposed group $(n=57)$ and the referent group $(n=31)$. Ratio (\%) of measured and predicted value from published reports ${ }^{17-19}$

\begin{tabular}{|c|c|c|c|c|c|c|c|c|}
\hline \multirow{3}{*}{$\begin{array}{l}\text { Lung function } \\
\text { test }\end{array}$} & \multicolumn{4}{|c|}{ Exposed } & \multicolumn{4}{|c|}{ Referents } \\
\hline & \multicolumn{2}{|c|}{ Observed } & \multicolumn{2}{|c|}{$\begin{array}{l}\text { Ratio obs/predicted } \\
(\%)\end{array}$} & \multicolumn{2}{|c|}{ Observed } & \multicolumn{2}{|c|}{$\begin{array}{l}\text { Ratio obs/predicted } \\
(\%)\end{array}$} \\
\hline & Mean & $S D$ & Mean & $S D$ & Mean & $S D$ & Mean & $S D$ \\
\hline $\begin{array}{l}\text { FVC (1) } \\
\text { FEV }_{1}(1) \\
\text { FEV\% }(\%) \\
\text { MMF (l/s) } \\
\text { CV (1) } \\
\text { CV\% }(\%) \\
\text { Phase III }\left(\% \mathrm{~N}_{2} / \mathrm{l}\right)\end{array}$ & $\begin{array}{r}4 \cdot 82 \\
3 \cdot 67 \\
76 \cdot 10 \\
3 \cdot 55 \\
0 \cdot 83 \\
18 \cdot 80 \\
1 \cdot 77\end{array}$ & $\begin{array}{l}0.98 \\
0.88 \\
7 \cdot 60 \\
1.40 \\
0.22 \\
5.70 \\
1.31\end{array}$ & $\begin{array}{r}92 \\
95 \\
103 \\
97 \\
95 \\
111 \\
146\end{array}$ & $\begin{array}{l}13 \\
16 \\
11 \\
35 \\
28 \\
36 \\
95\end{array}$ & $\begin{array}{r}5.02 \\
3.81 \\
76.00 \\
3.53 \\
0.83 \\
17.50 \\
1.41\end{array}$ & $\begin{array}{l}0.80 \\
0.71 \\
7.50 \\
1.44 \\
0.22 \\
5 \cdot 10 \\
0.94\end{array}$ & $\begin{array}{r}95 \\
97 \\
102 \\
94 \\
98 \\
107 \\
118\end{array}$ & $\begin{array}{l}11 \\
12 \\
11 \\
33 \\
25 \\
26 \\
72\end{array}$ \\
\hline
\end{tabular}

100 (FEV\%), and maximum mid-expiratory flow (MMF), calculated as the mean forced expiratory flow during the middle half of the FVC.

Two or three single breath nitrogen washouts were performed according to Anthonisen. ${ }^{16}$ Inspiratory and expiratory flow rates were kept at approximately $0.41 / \mathrm{s}$, as directed by the examiner. The expired nitrogen concentration was measured at the mouth with an ionisation meter (OHIO 720) and was recorded against the expired volume on an $\mathrm{X}$-Y-recorder (Bryans 26000). The slope of the alveolar plateau (phase III) and the closing volume (CV) were calculated as follows.

\section{Phase III}

Phase III is the slope of the alveolar plateau in per cent nitrogen per litre of expired gas as measured between $30 \%$ of expired vital capacity and onset of phase IV (see below) on the nitrogen volume recording.

\section{Closing volume}

Closing volume is the expired volume after the onset of phase IV, which was defined as the persisting departure of the nitrogen level from the alveolar plateau. A translucent ruler was used as an aid in defining the point of departure. Recording for which the flow rate had not been kept approximately constant, or where inspired and expired volumes differed by more than $10 \%$, were disregarded. Closing volume was expressed in per cent of the expired vital capacity (CV\%).

Standard references values for spirometry were taken from Berglund et al, ${ }^{17}$ whereas nitrogen washout data were compared with the normal values given by Buist and Ross. ${ }^{1819}$ Since the standard reference values do not discriminate between smokers and nonsmokers the predicted results for the exposed smokers and non-smokers were also calculated from the regression equations of the smoking and nonsmoking referents. The dependent variables were age, height, and smoking.

\section{STATISTICAL EVALUATION}

Differences in symptoms between the groups were analysed by chi square test with Yates's correction. The differences in the lung function tests between the groups and deviations from predicted values were

Table 4 Lung function data (spirometric and nitrogen washout data), age, and length for exposed and referent workers, smokers, and non-smokers

\begin{tabular}{|c|c|c|c|c|c|c|c|c|}
\hline \multirow{3}{*}{$\begin{array}{l}\text { Lung function } \\
\text { test }\end{array}$} & \multicolumn{4}{|c|}{ Exposed } & \multicolumn{4}{|c|}{ Referents } \\
\hline & \multicolumn{2}{|c|}{$\begin{array}{l}\text { Smokers } \\
(n=24)\end{array}$} & \multicolumn{2}{|c|}{$\begin{array}{l}\text { Non-smokers } \\
(n=33)\end{array}$} & \multicolumn{2}{|c|}{$\begin{array}{l}\text { Smokers } \\
(n=I 6)\end{array}$} & \multicolumn{2}{|c|}{$\begin{array}{l}\text { Non-smokers } \\
(n=15)\end{array}$} \\
\hline & Mean & $S D$ & Mean & $S D$ & Mean & $S D$ & Mean & $S D$ \\
\hline $\begin{array}{l}\text { FVC (1) } \\
\text { FEV } 1(1) \\
\text { FEV\% }(\%) \\
\text { MMF }(1 / \mathrm{s}) \\
\text { CV }(1) \\
\text { CV\% }(\%) \\
\text { Phase III }\left(\% \quad \mathrm{~N}_{2} / \mathrm{l}\right)\end{array}$ & $\begin{array}{r}4.88 \\
3.63 \\
74.04 \\
3 \cdot 30 \\
0 \cdot 86 \\
19 \cdot 33 \\
1.94\end{array}$ & $\begin{array}{l}0 \cdot 83 \\
0 \cdot 84 \\
7 \cdot 89 \\
1 \cdot 39 \\
0 \cdot 24 \\
6 \cdot 49 \\
1 \cdot 17\end{array}$ & $\begin{array}{r}4 \cdot 77 \\
3 \cdot 70 \\
77 \cdot 80 \\
3 \cdot 74 \\
0 \cdot 80 \\
18 \cdot 50 \\
1 \cdot 65\end{array}$ & $\begin{array}{l}1 \cdot 09 \\
0.92 \\
7 \cdot 21 \\
1 \cdot 41 \\
0 \cdot 20 \\
5 \cdot 19 \\
1 \cdot 42\end{array}$ & $\begin{array}{r}5 \cdot 31 \\
3.93 \\
74 \cdot 06 \\
3 \cdot 52 \\
0 \cdot 86 \\
17 \cdot 38 \\
1.45\end{array}$ & $\begin{array}{l}0.66 \\
0.57 \\
6.82 \\
1.01 \\
0.25 \\
5.38 \\
0.88\end{array}$ & $\begin{array}{r}4 \cdot 71 \\
3 \cdot 69 \\
78 \cdot 13 \\
3 \cdot 54 \\
0 \cdot 79 \\
17 \cdot 54 \\
1 \cdot 35\end{array}$ & $\begin{array}{l}0.83 \\
0.83 \\
7.95 \\
1.84 \\
0.17 \\
4.86 \\
1.04\end{array}$ \\
\hline $\begin{array}{l}\text { Age (years) } \\
\text { Length }(\mathrm{cm})\end{array}$ & $\begin{array}{r}46 \\
176\end{array}$ & $\begin{array}{r}10 \\
6\end{array}$ & $\begin{array}{r}48 \\
176\end{array}$ & $\begin{array}{r}13 \\
6\end{array}$ & $\begin{array}{r}42 \\
178\end{array}$ & $\begin{array}{r}12 \\
5\end{array}$ & $\begin{array}{r}48 \\
175\end{array}$ & $\begin{array}{r}14 \\
9\end{array}$ \\
\hline
\end{tabular}




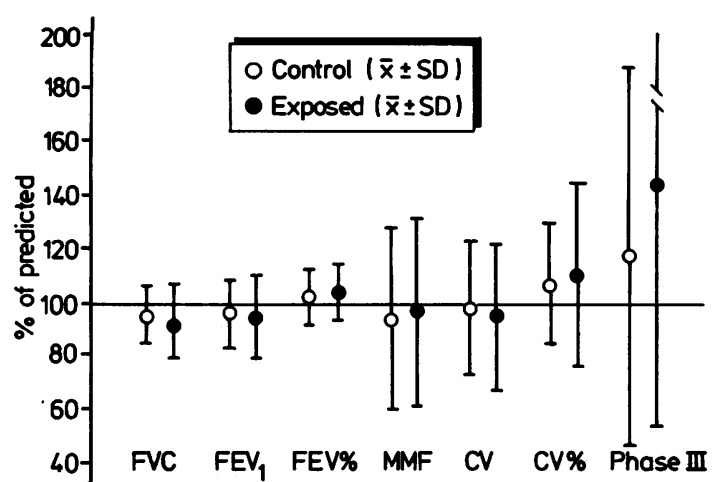

Fig 1 Ratio (\%) of measured and predicted spirometric and nitrogen washout data for referents $(n=31)$ and exposed workers $(n=57)$. Predicted values from published reports. ${ }^{17-19}$

tested using Student's paired two tailed $t$ test and correlations were calculated with Pearson's product moment correlation. Five per cent significance levels were used.

\section{Results}

The calculated cumulative dose estimate ranged from $0.34-9.9 \mathrm{mg} \mathrm{Cd} / \mathrm{m}^{3} \times$ year with a median of $1.7 \mathrm{mg} / \mathrm{m}^{3} \times$ year. The prevalence of raised $\beta_{2}$-microglobulinuria (levels exceeding $0.034 \mathrm{mg} / \mathrm{mmol}$ creatinine) was $42 \%$ and increased with the duration of cadmium exposure. ${ }^{13}$

Table 2 shows the frequency of symptoms in the exposed and referent groups. There were no significant differences between the two groups for any of the questions.

Spirometric and single breath nitrogen washout variables for the exposed and the referents were all within predicted limits, when compared with standard references, and there were no significant differences between the exposed group and the reference group neither in total (tables 3 and 4, fig 1) nor when the exposed group was dichotomised (figs 2 and 3) into "high exposed" ( $\geqslant 1.70 \mathrm{mgCd} / \mathrm{m}^{3} \times$ year) and "low exposed" ( $<1.70 \mathrm{mg} \mathrm{Cd} / \mathrm{m}^{3} \times$ year $)$ or with regard to $\beta_{2}$-microglobulinuria (U- $\beta_{2}$ $>0.034 \mathrm{mg} / \mathrm{mmol}$ creatinine). No significant correlations were found between lung function and accumulated exposure time or the cumulative dose estimate.

There were $24(42 \%)$ smokers among the exposed and $16(52 \%)$ in the non-exposed group (table 1), this difference was not significant. To evaluate the possible influence of smoking, data from smokers and nonsmokers were treated separately and the statistical

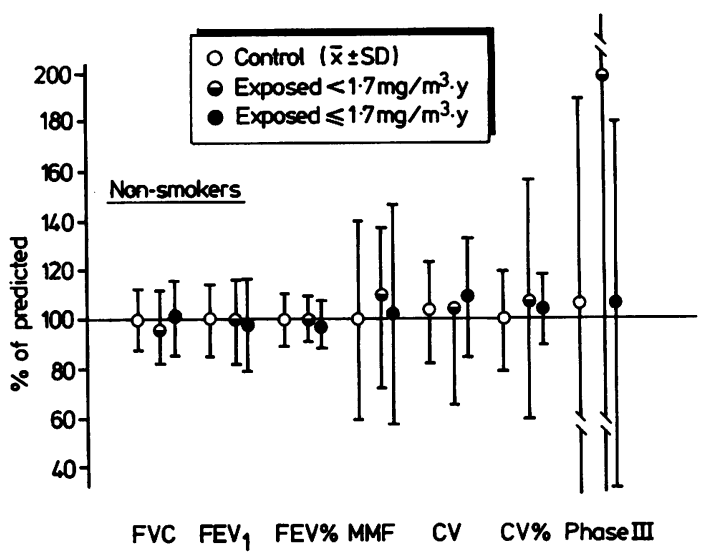

Fig 2 Non-smokers. Ratio (\%) of measured spirometric and nitrogen washout data in referents and exposed workers. Predicted values calculated from referents (age and height adjusted). Referents $(n=15)$, low exposed

$\left(<1.7 \mathrm{mg} C d / \mathrm{m}^{3} \times\right.$ year $)(n=12)$ and high exposed $\left(\geqslant 1.7 \mathrm{mgCd} / \mathrm{m}^{3} \times\right.$ year $)(n=21)$.

analysis showed no significant impairment in lung function between smoking exposed and non-smoking exposed and smoking unexposed and non-smoking unexposed, or when exposed smokers were compared with unexposed smokers and exposed non-smokers with unexposed non-smokers, respectively (table figs 2 and 3). There was a slight tendency towards an increase in phase III (table 4, figs 2 and 3). b the exposed workers, although this did not attain statistical significance.

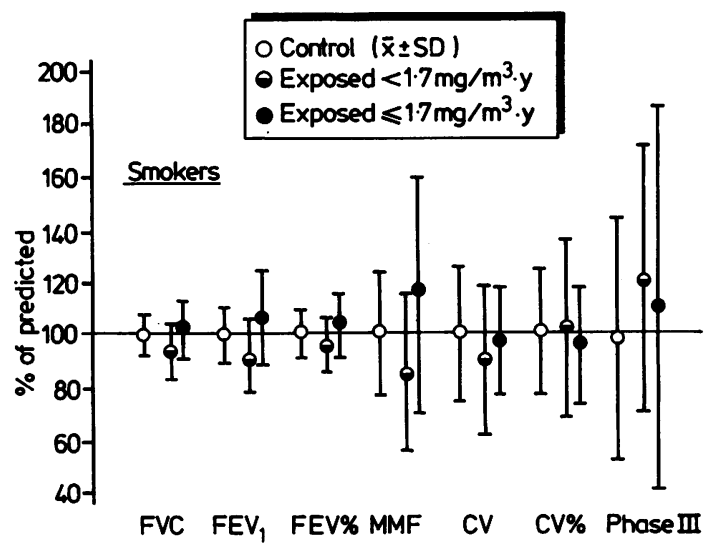

Fig 3 Smokers. Ratio (\%) of measured spirometric and nitrogen washout data in exposed workers. Predicted values calculated from referents (age and height adjusted).

Referents $(n=16)$, low exposed $\left(<1.7 \mathrm{mg} \mathrm{Cd} / \mathrm{m}^{3} \times\right.$ year $)$ $(n=14)$, and high exposed $\left(\geqslant 1.7 \mathrm{mg} \mathrm{Cd} / \mathrm{m}^{3} \times\right.$ year $)$ $(n=10)$. 


\section{Discussion}

The results of the renal function tests indicate that the workers had been heavily exposed to cadmium, and to such a degree that tubular damage was evident in more than $40 \%$ of the exposed. Despite this there were no significant differences between exposed and non-exposed when symptoms (table 2) and lung function tests were compared (tables 3 and 4). This indicates that the kidneys rather than the lungs are the critical organ for long term occupational exposure to cadmium.

Although the study is of a non-experimental design, the exposed group and the reference group were comparable with regard to sex, age, and height, factors known to influence the lung function tests. The results could be explained by a selection bias if people employed more than five years had changed their occupation because of lung disease and only "healthy workers" were left. In this study, however, retired workers and those who had moved elsewhere were examined and the drop outs were mainly among people still working at the plant who had no known lung disorders when checked with the occupational health care unit. Neither were the causes of death for the two who had died related to cadmium exposure.

It has been suggested that cadmium induced pulmonary effects are of the chronic obstructive type, mainly affecting the small airways. ${ }^{11}$ Therefore we used lung function tests (closing volume and phase III) which are considered to be particularly sensitive in identifying small airway disease. ${ }^{20}$ As indicated by the standard deviations in tables 3 and 4 and in the figures, however, the variability of these lung function tests may be relatively large. This experience is shared by other investigators ${ }^{2122}$ but cannot be supposed to invalidate the results when discriminating between groups.

The prevalence of various self reported symptoms and earlier diseases varied somewhat between the exposed men and the referent group (table 2). The men exposed to cadmium more often reported symptoms of non-productive and productive cough, indicative of airways irritation (table 2). On the other hand, the referents had a higher frequency of bronchitis and complaints of breathlessness. None of these differences was statistically significant $(p>0.05)$, however. The overall pattern of complaints (table 2) suggested that there were no major differences between the two groups. It should be pointed out, however, that the referent group comprised industrial workers occupied on similar work (soldering) as the exposed men, although they had not previously been exposed to cadmium. The frequency of symptoms and previous diseases may well have differed if, for example, white collar workers had been examined.
The purpose of this study was to examine the possible effect from cadmium and not that of soldering or welding.

Additional analyses were undertaken to assess the dose-response relation within the exposed group by using the cumulative years of cadmium exposure or the estimated cumulative dose. Such analyses showed no evidence of chronic respiratory effects associated with long term or high cadmium exposure.

The proportion of smokers differed slightly between the two groups, more smokers being present among the unexposed. Since smoking commonly results in decreased lung function, a higher proportion of smokers in the reference group would tend to impair the spirometric and single breath nitrogen washout variables and thereby possibly conceal any difference between the groups. Therefore the analyses were also made comparing exposed and non-exposed smokers and exposed and non-exposed non-smokers (table 4, figs 2 and 3), but no significant differences between these groups were seen. We found, however, that smokers had somewhat deteriorated in CV and phase III when compared with non-smokers, regardless of exposure status (table 4). This is in accordance with the previous experience that smoking affects the smaller airways and that $\mathrm{CV}$ and phase III become abnormal before $\mathrm{FEV}_{1}$ and that the response to occupational dust exposure may differ from that to tobacco smoking. ${ }^{23}$

The lowest concentration of cadmium in workroom air that has been associated with obstructive pulmonary function tests has been about $70 \mu \mathrm{g} \mathrm{Cd} / \mathrm{m}^{3}$ as total dust and $20 \mu \mathrm{g} \mathrm{Cd} / \mathrm{m}^{3}$ as respirable dust and more than 20 years of exposure. ${ }^{7}$ This would correspond to a cumulative dose estimate of about $0.5 \mathrm{mg} \mathrm{Cd} / \mathrm{m}^{3} \times$ year $\left(25\right.$ years $\left.\times 20 \mu \mathrm{g} \mathrm{Cd} / \mathrm{m}^{3}\right)$. Respiratory effects at that low level of cadmium exposure could not be confirmed in the present study where the median cumulative exposure was $1.7 \mathrm{mg} \mathrm{Cd} / \mathrm{m}^{3} \times$ year. In view of the findings in previous cross sectional studies of cadmium exposed workers ${ }^{1-511}$ and the increased mortality from obstructive lung diseases that has been observed in several epidemiological studies of cadmium workers ${ }^{24-26}$ and the results from animal studies ${ }^{12728}$ it seems clear that heavy cadmium exposure may induce severe obstructive lung diseases. Furthermore, the immediate hazards from inhalation of high concentrations of cadmium fumes $\left(>5 \mathrm{mg} \mathrm{Cd} / \mathrm{m}^{3}\right.$ ) should be remembered. This may cause severe and fatal pulmonary oedema. ${ }^{1029}$

According to our data, renal effects in the form of low molecular weight proteinuria precede respiratory symptoms and signs. This is in accordance with the result of a cross sectional study of cadmium workers in Belgium, ${ }^{8}$ whereas Sakurai et al reported that pulmonary effects were as prevalent as renal ones. ${ }^{11}$ The 
average exposure of the seven cadmium exposed Japanese workers examined by Sukarai et al was, however, considerably higher $\left(5 \mathrm{mg} \mathrm{Cd} / \mathrm{m}^{3} \times\right.$ year $)$ compared with our group $\left(1.7 \mathrm{mg} \mathrm{Cd} / \mathrm{m}^{3} \times\right.$ year $)$.

The differences between this study and the others may therefore be primarily due to the differences in the concentrations to which the subjects were exposed. Taking into account also the effects on the kidneys, ${ }^{1314}$ our results indicate that a time weighted average for respirable cadmium dust in air should be kept below $0.025 \mathrm{mg} \mathrm{Cd} / \mathrm{m}^{3}$ to prevent the pulmonary or renal effects of long term occupational exposure to cadmium.

\section{References}

1 Friberg L. Health hazards in the manufacture of alkaline accumulators with special reference to chronic cadmium poisoning. Acta Med Scand 1950;suppl 240:1-124.

2 Lane RE, Campbell ACP. Fatal emphysema in two men making a copper-cadmium alloy. Br J Ind Med 1954;11:118-22.

3 Bonnell JA. Emphysema and proteinuria in men casting coppercadmium alloys. $B r J$ Ind Med 1955;12:181-97.

4 Kazantzis G. Respiratory function in men casting cadmium alloys. Br J Ind Med 1956;13:113-6.

5 Kazantzis G, Flynn FV, Spowage JS, Trott DG. Renal tubular malfunction and pulmonary emphysema in cadmium pigment workers. QJ Med 1963;32:165-92.

6 Baader EW. Die chronische Kadmiumvergiftung. Dtsch Med Wochenschr 1951;76:484-7.

7 Lauwerys RR, Buchet J-P, Roels HA, Brouwers J, Stanescu D. Epidemiological survey of workers exposed to cadmium. Arch Environ Health 1974;28:145-8.

8 Lauwerys RR, Roels HA, Buchet J-P, Bernard A, Stanescu D. Investigations on the lung and kidney function in workers exposed to cadmium. Environ Health Perspect 1979;28:137-45.

9 Stanescu D, Veriter C, Frans A, et al. Effects on lung of chronic occupational exposure to cadmium. Scand J Respir 1977; 58:289-303.

10 Parkes WR. Occupational lung disorders. 2nd ed. London: Butterworths, 1982:457-63.

11 Sakurai H, Omae K, Toyama T, Higashi T, Nakadate T. Crosssectional study of pulmonary function in cadmium alloy workers. Scand J Work Environ Health 1982;8(suppl 1):122-30.

12 Hallne U, Bergström B, Hallberg B-O. Measurements of air pollutants during welding and soldering. Solna: National Board of Occupational Safety and Health, 1977. (Report No 1977:300.) (In Swedish.)

13 Elinder C-G, Edling C, Lindberg E, Kågedal B, Vesterberg $O$. Beta-2-microglobulinuria among workers previously exposed to cadmium. Follow-up and dose-response analyses. Am J Ind Med 1985;8:553-64.

14 Elinder C-G, Edling C, Lindberg E, Kågedal B, Vesterberg O. Assessment of renal function among workers previously exposed to cadmium. Br J Ind Med 1985;42:754-60.

15 Gardner RM. ATS statement-Snowbird workshop on standardization of spirometry. Am Rev Respir Dis 1975;119:831-8.

16 Anthonisen NR. Report of informal session on "closing volume" determinations. Bethesda: National Heart Lung Institute, 1972.

17 Berglund E, Birath G, Bjure J, et al. Spirometric studies in normal subjects. Acta Med Scand 1963;173:185-98.

18 Buist AS, Ross BB. Predicted values for closing volumes using a modified single breath nitrogen test. Am Rev Respir Dis 1973;107:744-52.

19 Buist AS, Ross BB. Quantitative analysis of the alveolar plateau in the diagnosis of early airway obstruction. Am Rev Respir Dis 1973;108:1078-87.

20 Petty TL, Silvers GW, Stanford RE, Baird MD, Mitchel RS Small airway pathology is related to increased closing capacity and abnormal slope of phase III in excised human lungs. Am Rev Respir Dis 1980;298:1277-81.

21 Sjögren B, Hedenstierna G. Pulmonary function and concentrations of alpha $\mathbf{1}_{1}$-antitrypsin and immunoglobulin $\mathrm{E}$ in workers exposed to pancreatic enzymes. Scand $J$ Work Environ Health 1983;9:385-90.

22 Love RG, Attfield MD, Isles KD. Reproducibility of pulmonary function tests under laboratory and field conditions. $\mathrm{Br} J$ Ind Med 1980;37:63-9.

23 Rasmussen FV. Occupational dust exposure and smoking. Different effects on forced expiration and slope of the alveolar plateau. Eur J Respir Dis 1985;66:119-27.

24 Kjellström T, Friberg L, Rahnster B. Mortality and cance्巳 morbidity among cadmium-exposed workers. Environ Heal Perspect 1979;28:199-204.

25 Holden H. A mortality study of workers exposed to cadmiuff fumes. In: Cadmium 79. Edited proceedings, Second international cadmium conference, Cannes, 6-8 February 1979. London: Cadmium Association, 1980:211-5.

26 Armstrong BG, Kazantzis G. The mortality of cadmium workers. Lancet 1983;i:1425-7.

27 Prigge E. Early signs of oral and inhalative cadmium uptake in rats. Arch Toxicol 1978;40:231-47.

28 Snider GL, Hayes JA, Korthy AL, Lewis GP. Centrilobular emphysema experimentally induced by cadmium chloride aerosol. Am Rev Respir Dis 1973;108:40-8.

29 MacFarland HN. Pulmonary effects of cadmium. In: Mennear JH, ed. Cadmium toxicity. Vol 15. New York: Marcel Dekker, 1979:113. 